\title{
Tal Ilan
}

\section{Lexicon of Jewish Names in Late Antiquity}

Part II: Palestine 200-650

[Lexikon jüdischer Namen in der Spätantike. Teil 2: Palästina 200-650.]

Veröffentlicht auf Englisch.

Dies ist der letzte Band, der in dieser vierteiligen Reihe veröffentlicht wird. Dieser Band listet alle Juden aus Palästina auf, die namentlich erwähnt wurden und zwischen dem Jahr 200 v. Chr. und vor der Islamischen Expansion lebten. Als Quelle dienten hauptsächlich der Palästinische Talmud und Grabinschriften auf jüdischen Friedhöfen wie Beit Shearim. Anders als in den vorangegangenen Bänden dieser Reihe werden auch alle namentlich bekannten Samariter Palästinas aus dieser Zeit aufgeführt. Der Band beinhaltet mehr als 3000 Einträge. Mit den anderen zusammengerechnet ergibt das eine Zusammenstellung von mehr als 15000 genannten Juden. Enthalten ist auch ein umfangreiches Addendum zu Band 1 , welcher vor genau 10 Jahren veröffentlicht wurde. Ein Anhang stellt die Ergebnisse der Untersuchungen von Inschriften in der Elija-Höhle in Haifa durch die Projektgruppe dar. Den Mitgliedern der Arbeitsgruppe gelang es, 50 Inschriften zu entziffern، wodurch mehr als 70 Namen zum vorliegenden Band hinzugefügt werden konnten.

Tal Ilan Born 1956; 1991 PhD on Jewish Women in Greco-Roman Palestine at the Hebrew University in Jerusalem; 2003-22 Professor for Jewish Studies at the Freie Universität, Berlin; 2022 retired; since 2008 she is the editor of the Feminist Commentary on the Mishnah and the Babylonian Talmud (FCBT).

2012. XXVIII, 621 Seiten. TSAJ 148

ISBN 978-3-16-152137-9

DOI 10.1628/978-3-16-152137-9

eBook PDF $254,00 €$

ISBN 978-3-16-150207-1

Leinen $254,00 €$

Jetzt bestellen:

https://mohrsiebeck.com/buch/lexicon-of-jewish-names-in-late-antiquity-9783161521379?no_cache=1 order@mohrsiebeck.com

Telefon: +49 (0)7071-923-17

Telefax: $+49(0) 7071-51104$ 